\title{
Acanthodian jaw bones from Lower Devonian marine deposits of Podolia, Ukraine
}

Victor Voichyshyn and Hubert Szaniawski

Acta Palaeontologica Polonica 57 (4), 2012: 879-896 doi: http://dx.doi.org/10.4202/app.2011.0079

Ischnacanthiform acanthodian dentigerous jaw bones from the Lower Devonian (Late Lochkovian) of Podolia are described for the first time. One new genus and one new species are established. Podoliacanthus gen. nov. is diagnosed as having small-sized jaw bones, the presence of specific accessory cusps/denticles on the medial side of teeth of the lateral tooth row, and groups of denticles forming the lingual tooth row. Podoliacanthus zychi sp. nov. is distinguished in having elongated slender jaw bones and lateral teeth with one medial side denticle. Besides, three species are described in open nomenclature: Podoliacanthus sp. 1, while similar to Podoliacanthus zychi sp. nov., differs in having stronger posterior inclination of the teeth tips and presence of well developed flanges of the teeth, Podoliacanthus sp. 2 has quite robust jaw bones and teeth with two medial side denticles, and Podoliacanthus sp. 3 has small narrow jaw bones and teeth with three medial side denticles. Morphology of the lingual tooth row is considered to be a diagnostic feature of generic and higher taxonomic levels, while accessory medial cusps/denticles of the teeth are regarded as diagnostic features at species level. The new genus also occurs in Upper Silurian or Lower Devonian deposits of North Greenland. Preservation of the jaw bones possibly depends on their secondary mineralization.

Key words: Acanthodii, Ischnacanthiformes, dentigerous jaw bone, Devonian, Lochkovian, Podolia.

Victor Voichyshyn [victor@museum.lviv.net], State Museum of Natural History NASU, Teatralna Str. 18, 79008, L'viv, Ukraine; Hubert Szaniawski [szaniaw@twarda.pan.pl], Instytut Paleobiologii PAN, ul. Twarda 51/55, PL-00-818 Warszawa, Poland.

This is an open-access article distributed under the terms of the Creative Commons Attribution License (for details please see creativecommons.org), which permits unrestricted use, distribution, and reproduction in any medium, provided the original author and source are credited. 
PaF Full text $(1,713.0 \mathrm{kB})$ 